Article

\title{
Experimental Investigations on Lateral Dispersion Coefficients of Fuel Particles in Large-Scale Circulating Fluidized Bed Boilers with Different Coal Feeding Modes
}

\author{
Jin Yan ${ }^{1,2, * \mathbb{C}}$, Xiaofeng $\mathrm{Lu}^{2}$, Xiong Zheng ${ }^{2}$, Rui Xue ${ }^{1}$, Xiujian Lei ${ }^{3}$, Xuchen Fan ${ }^{2}$ and \\ Shirong Liu ${ }^{4}$ \\ 1 College of Energy and Power Engineering, Nanjing Institute of Technology, Nanjing 211167, China; \\ xuerui@njit.edu.cn \\ 2 Key Laboratory of Low-Grade Energy Utilization Technologies and Systems, Ministry of Education of PRC, \\ Chongqing University, Chongqing 400044, China; xfluke@cqu.edu.cn (X.L.); x.zheng@cqu.edu.cn (X.Z.); \\ 20181001003@cqu.edu.cn (X.F.) \\ 3 Sichuan Baima CFB Demonstration Power Plant Co. Ltd., Neijiang 641005, China; 17038633@shenhua.cc \\ 4 Datang Wu'an Power Plant Co. Ltd., Handan 056300, China; zjb@cdt-wafd.com \\ * Correspondence: jinyan@njit.edu.cn
}

Received: 23 October 2020; Accepted: 28 November 2020; Published: 1 December 2020

check for updates

\begin{abstract}
The dispersion characteristics of fuel particles over the bed have always been a key consideration in the design of fluidized beds. However, the lateral fuel dispersion coefficients $\left(D_{s r}\right)$ reported in the previous literature widely ranged from $10^{-4}$ to $10^{-1} \mathrm{~m}^{2} / \mathrm{s}$, which were hard to be directly applied in large-scale CFB (circulating fluidized bed) boilers with wider bed width (close to $30 \mathrm{~m}$ ) and variable coal feeding modes. To solve this problem, field tests were conducted on the first $600 \mathrm{MW}$ CFB boiler in this paper, and the distributions of flue gas composition and flue gas temperature were obtained near the coal feeding port under four working conditions. The dispersion characteristics of fuel particles were analyzed in detail combined with the dispersion model. In addition, a new method based on bed heat balance was also proposed to estimate $D_{s r}$ and applied in a $300 \mathrm{MW}$ CFB boiler with a different coal feeding mode. The results revealed that $D_{s r}$ through the local heat balance method ranged from $0.10-0.35 \mathrm{~m}^{2} / \mathrm{s}$, which were $9-18 \%$ higher than the values through the dispersion model. Compared with the coal feeding port immersed in the bed, $D_{s r}$ of the fuel particles fed into the splash zone increased by about $34.7 \%$. $D_{s r}$ under the coal feeding mode of a screw feeder with pressurized air ranged from $0.12-0.16 \mathrm{~m}^{2} / \mathrm{s}$, which were lower than $D_{s r}$ under the coal feeding method of importing fuel into circulating ash. The method and results in this paper could expand the applicability of fuel dispersion, and provide the most direct guidance for the design and optimization of coal feeding ports in large-scale CFB boilers.
\end{abstract}

Keywords: CFB; dispersion coefficient; heat balance; flue gas composition

\section{Introduction}

In recent decades, the circulating fluidized bed (CFB) boiler has been widely adopted because of the advantages in the treatment of low-grade energy and pollutant control, and is developing towards the direction of large capacity and high parameters [1-8]. With the increasing furnace dimensions, a series of non-uniform problems in gas-solid flow and combustion appear to be more and more obviously $[9,10]$. One of the most important factors is the mixing characteristics of fuel particles in the dense phase zone. On one hand, the uniformity of reactant distribution over the cross-section of the 
bed depends on the reaction rate and lateral particle dispersion. If the dispersion rate is lower than the reaction rate, it shows to be a non-uniform distribution. On the other hand, the operating commercial CFB boilers are often with higher bed width to depth ratios, and the numbers of coal feeding ports in a fluidized bed with a large cross-section are limited for cost reasons, which will makes it critical for fuel mixing over the bed, affecting the combustion stability as well as pollutant generation and distribution in the dense phase zone. Thus, the shortages of the fuel dispersion process have seriously hindered the scale-up and diversified development of CFB boilers.

Particle mixing and dispersion in dense phase zone is one of the important problems in the fundamental research of fluidization; Kunii and Levenspiel [11] first proposed the bubble bed mechanism model. Svensson [12] found that the particle dispersion characteristics in the fast bed should be similar to that of the bubbled bed so the investigation methods could be consistent. After decades of research [13-22], scholars believed that the factors affecting particle mixing included particle size and density, fluidization air distribution, static bed height and bed width, and the dispersion coefficient $D_{s r}$ was generally introduced to describe this dispersion ability [23,24], which was derived from the Fickian-type diffusion equation. Some scholars [25] defined this quantitative description as the macroscopic method of particle dispersion. By means of particle tracking (both experiments and CFD simulations), many lateral dispersion coefficients in fluidization systems of various dimensions have been obtained. In contrast, based on the Einstein's Brownian motion theory, the particle dispersion coefficient can also be solved by tracking the trajectory information of a single particle in a period of time. Some typical approaches and calculation results are listed in Table 1.

Table 1. Some work predicting the lateral dispersion coefficient of solids in fluidization systems.

\begin{tabular}{ccccc}
\hline Ref & Technique & State & Bed Size $(\mathbf{m})$ & Disp. Coeff. $\left(\mathbf{m}^{2} \mathbf{s}\right)$ \\
\hline Liu [26] & Thermal tracer & Cold & $0.3 \times 0.2$ & $0.00025-0.0025$ \\
\hline Olsson [27] & Phosphorescent particle tracking & Cold & 1.44 & $0.00024-0.00124$ \\
\hline Hu [28] & Thermal tracer & Cold & $0.8 \times 1.2$ & $0.06-0.4$ \\
\hline Schlichthaerle [29] & Sublimating CO $/$ thermal tracer & Cold & $1 \times 0.3$ & 0.12 \\
\hline Yang [30] & Thermal tracer & Cold & $0.9 \times 0.1$ & $0.0032-0.0126$ \\
\hline Gan [31] & Particle size tracer & Cold & $0.9 \times 0.2$ & $0.0005-0.0025$ \\
\hline Oke [32] & Euler-Euler & Cold & $0.01 \times(0.2-1)$ & $0.001-0.0135$ \\
\hline Oke [33] & CFD-DEM & Cold & $0.05 \times 0.6$ & $0.00015-0.025$ \\
\hline Chirone [34] & CFD-DEM & Thermal & $\mathrm{D}=0.37$ & $/$ \\
\hline
\end{tabular}

A significant amount of work on solids mixing in fluidized beds are available in the literature. However, two shortcomings are remain with regard to lateral fuel dispersion: (1) the source term was not considered in the traditional dispersion model. For a CFB boiler of at least industrial-grade, it is difficult to eliminate the momentum of returning materials immediately after entering the furnace. In other words, the distribution of fuel concentration following dispersion law is strongly affected by its initial concentration distribution, which is hardly to be predicted through the cold test apparatus. Unfortunately, most of the experiments were conducted under the cold state. (2) The research objects were mostly lab-scale or two-dimensional fluidized beds, so the influence of bed width on the dominant factors of the particle mixing mechanism is still uncertain. In addition, the reported lateral dispersion coefficients differ up by over three orders of magnitude, so the previous results cannot be directly applied to large-scale furnace with higher bed width to depth ratio. To the author's knowledge, the prediction based on the field test of supercritical CFB boilers with different coal feeding modes have not yet been reported. Therefore, the purpose of this paper is to explore lateral dispersion characteristics of fuel particles in large-scale CFB boilers and to quantify the corresponding lateral dispersion coefficients. Specifically, the authors carried out comprehensive field tests in the coal feeding zones of the first $600 \mathrm{MW}$ CFB boiler. According to the measured flue gas composition and temperature, 
the dispersion distance and trajectory of coal particles were determined, and the influence of operating parameters on fuel dispersion characteristics were also analyzed in detail. Then, a new prediction method based on local heat balance was proposed to estimate $D_{s r}$, and the results were compared with those adopted the traditional dispersion model. Eventually, this new method was applied and validated in another 300 MW CFB boiler with a different coal feeding mode. The method in this paper can provide a convenient approach to predict the dispersion process of fuel particles under different conditions, and the calculated $D_{s r}$ can also make up for its shortcomings in the application of various industrial-grade CFB boilers effectively.

\section{Experimental Section}

\subsection{Description of the $600 \mathrm{MW}$ CFB Boiler}

As shown in Figure 1, the 600 MW CFB boiler adopts the pant-leg design with twin furnaces and air distributors at two sides. Also, it is separated by double-exposed division walls. The cross-section of the upper furnace is $15 \mathrm{~m}$ (width) $\times 28 \mathrm{~m}$ (depth), and the height of the furnace is $55 \mathrm{~m}$. Six steam-cooled cyclones and six EHEs (external heat exchangers) are arranged on the two sides of the boiler [35,36]. Six coal feeding ports are arranged at each loop seal and EHE of one furnace side. The fuel enters the furnace after mixing with circulating ash. Part of the high-temperature circulating ash directly enters the furnace through six loop seals, the rest is fed into the EHEs to heat the steam, and then enters the furnace with lower temperature. By controlling the solid flux of circulating in the EHEs, the temperatures of bed and steam can be adjusted [37].

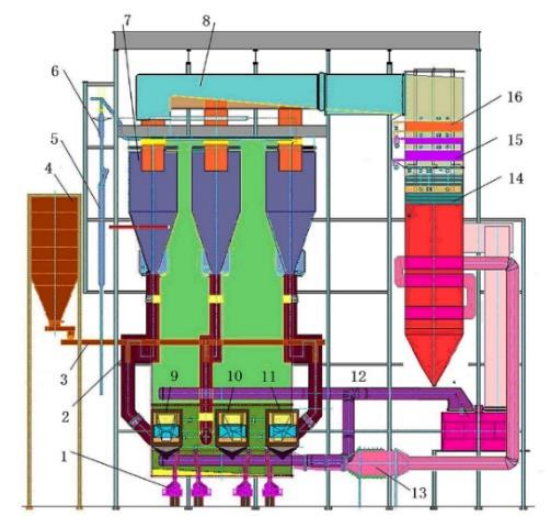

Figure 1. Schematic diagram of the 600 MW CFB boiler (1-slag cooler; 2-material returning device; 3-coal feeding route; 4-coal bunker; 5-storage tank; 6-steam separator; 7-cyclone separator; 8-flue duct; 9-11-external heat exchangers (EHEs); 12-secondary air duct; 13-ignition duct; 14-economizer; 15-low temperature reheater; 16-low temperature superheater).

\subsection{Experiment Procedure}

Due to the symmetrical structure of the boiler, only the right furnace was tested. It is well known that the particle mixing could be extremely affected by the secondary air (SA) jet, so the coal feeding port near the furnace corner of the rear wall was selected for the field test. Figure 2 exhibits the layout diagram of the measurement ports, where the blue arrows indicate the primary air (PA) and part of the SA nozzles, and the red marks indicate the coal feeding inlets (the return tubes are not shown in this figure). The lower and upper measurement ports are composed of casings and sealed ball valves, which are $0.82 \mathrm{~m}$ from the rear wall and $1.93 \mathrm{~m}$ and $7.50 \mathrm{~m}$ from the air distributor respectively. 


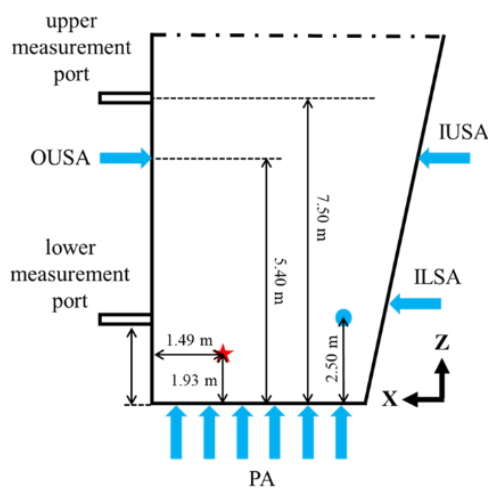

(a) front view (from rear wall)

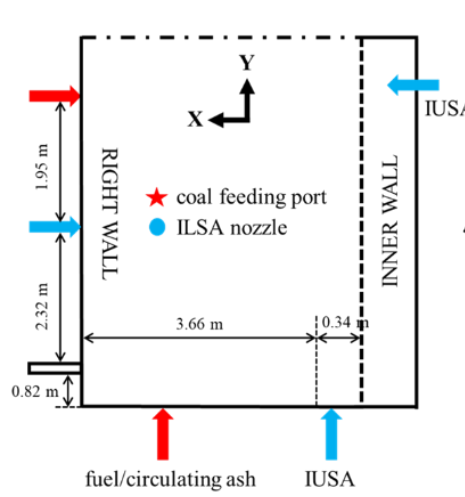

(b) vertical view

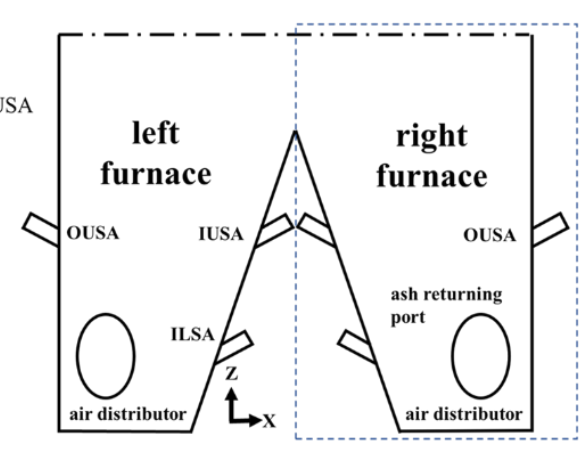

(c) front view (from front wall)

Figure 2. A schematic diagram of the upper/lower measurement ports and the air/coal feeding positions in adjacent zones ((a)-measurement ports from front view at the rear wall; (b)-measurement port from vertical view; (c)-arrangements of the secondary air and coal feeding port/ash returning port; ILSA-inner lower SA; IUSA-inner upper SA; OUSA-outer upper SA).

A 316 stainless steel tube with an outer diameter of $18 \mathrm{~mm}$ was adopted as the sampling probe in this test. Because of the high bed pressure at the bottom of the dense phase zone, the low measurement port was used to measure the temperature, and the upper measurement port was used to obtain the flue gas composition along the horizontal direction of the furnace width. The maximum sampling depth was close to $3 \mathrm{~m}$, the replicated measurements were conducted when the probe was pulled out. As the selected coal feeding port shown in Figure 2 was about $1.5 \mathrm{~m}$ from the right wall, the maximum sampling depth could characterize the lateral dispersion process of the fuel entering the furnace.

The flue gas analysis system was mainly composed of the sampling probe, an air filter apparatus, a vacuum pump with straight tee, an ash filter apparatus and an Ecom-J2KN type flue gas analyzer (measurement accuracy: oxygen-0.2\%, other composition-10 ppm). As the dynamic distribution of the flue gas composition showed to be sinusoidal [38], at least two trough values of each composition were recorded to guarantee the repeatability of the tests. To avoid chemical reactions of the extracted flue gas with the long sampling probe, this probe was equipped with corundum as inside lining. This method has been adopted in our measurement of other CFB boilers. In addition, limited by the special location of the measurement ports and narrow fin width between the membrane tubes, it was impossible to adopt the water-cooled sampling device, so the flue gas could continue to react in the sampling probe. In this case, the sampled gas composition could deviate from the actual situation. After strict comparative tests [39], the authors found that the measurement deviations of $\mathrm{O}_{2}$ and $\mathrm{CO}$ were no more than $-4 \%$ and $8.6 \%$ respectively with and without water-cooling, and the influence of $\mathrm{SO}_{2}$ condensation could be ignored under this sampling condition. Thus, the final results of the measured values have been updated accordingly.

\subsection{Working Conditions Arrangement}

To predict the lateral fuel dispersion coefficients and discern the main influencing factors, four sets of comparative experiments under 100\%, 75\% and 60\% BMCR (Boiler Maximum Continuous Rating) loads were carried out, i.e., Case 1 to Case 4 in Table 2. The proximate analysis and particle size distributions of the feeding coal are exhibited in Table 3 and Figure 3, respectively. 
Table 2. Main operating parameters of the boiler during the tests.

\begin{tabular}{cccccc}
\hline Item & Unit & Case 1 & Case 2 & Case 3 & Case 4 \\
\hline Load & $\mathrm{MW}$ & 360 & 360 & 451 & 600 \\
\hline Coal feeding rate & $\mathrm{t} / \mathrm{h}$ & 158 & 166 & 202 & 264 \\
\hline Bed height & $\mathrm{mm}$ & 800 & 1000 & 800 & 800 \\
\hline PA flow rate & $\mathrm{m}^{3} / \mathrm{s}$ & 129 & 138 & 142 & 163 \\
\hline SA flow rate & $\mathrm{m}^{3} / \mathrm{s}$ & 117 & 109 & 165 & 227 \\
\hline Bed pressure & $\mathrm{kPa}$ & 6.7 & 7.1 & 6.8 & 5.3 \\
\hline Temperature of hot circulating ash & ${ }^{\circ} \mathrm{C}$ & 849 & 850 & 868 & 916 \\
\hline
\end{tabular}

Table 3. Proximate analysis of the feeding coal under various working conditions ( $\mathrm{A}_{\mathrm{ad}}$-ash; $\mathrm{M}_{\mathrm{ad}}$-moisture; $\mathrm{V}_{\text {ad}}$-volatiles; $\mathrm{Fc}_{\mathrm{ad}}$-fixed carbon @ air dry basis, wt $\%$ ).

\begin{tabular}{cccccc}
\hline Item & Unit & Case 1 & Case 2 & Case 3 & Case 4 \\
\hline $\mathrm{Q}_{\text {net,ad }}$ & $\mathrm{MJ} / \mathrm{kg}$ & 19.25 & 19.83 & 20.81 & 20.94 \\
$\mathrm{~A}_{\mathrm{ad}}$ & $\%$ & 18.12 & 17.92 & 17.39 & 17.86 \\
$\mathrm{M}_{\mathrm{ad}}$ & $\%$ & 11.63 & 11.02 & 12.4 & 12.6 \\
$\mathrm{~V}_{\mathrm{ad}}$ & $\%$ & 21.32 & 21.37 & 18.6 & 17.48 \\
$\mathrm{Fc}_{\mathrm{ad}}$ & $\%$ & 48.93 & 49.69 & 51.61 & 52.06 \\
\hline
\end{tabular}

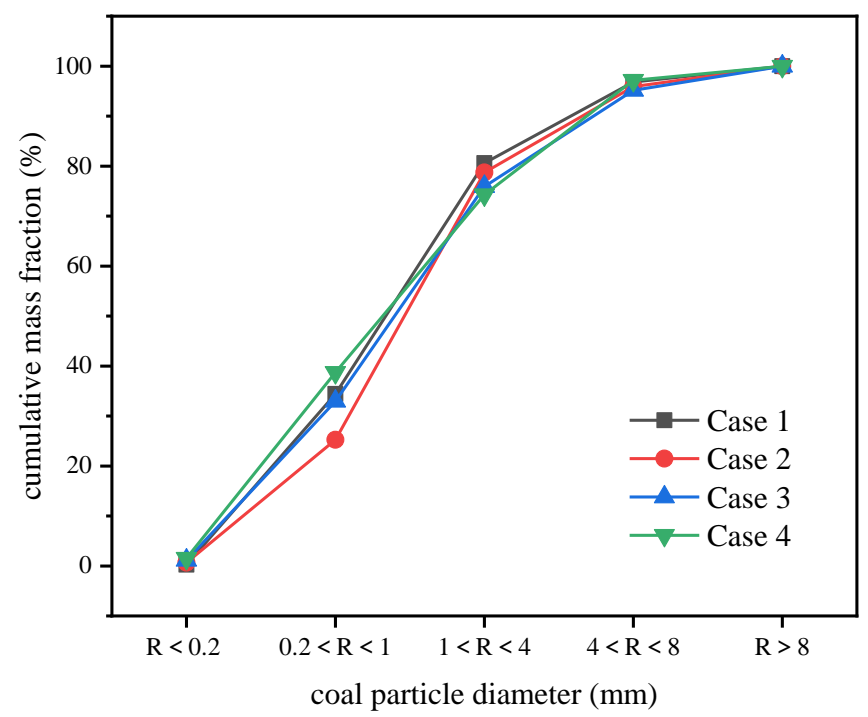

Figure 3. Particle size distributions of the feeding coal under various working conditions.

\section{Calculation Methodology}

\subsection{Prediction of Lateral Dispersion Coefficient Based on Macroscopic Dispersion Model}

In this 600 MW CFB boiler, the fluidization air is evenly distributed in the local area [40], and the coal and limestone powder entering the furnace are evenly mixed. The limestone with small size is mainly distributed in the upper part of the furnace, while the coal with larger size may remain in the bottom part. Thus, it can be considered that the coal is relatively more than limestone in the region with higher $\mathrm{SO}_{2}$ concentration, the coal is more than fluidization air in the region of higher $\mathrm{CO}$ concentration and the region with higher $\mathrm{NO}_{X}$ concentration corresponds to the area of more volatile matter or oxygen. In addition, if the coal type was changed, the distributions of temperature and flue gas composition were bound to update with the change of fuel dispersion. Therefore, whatever the fuel type is, the updated concentration distributions of flue gas composition can also correspond 
to the coal feeding distributions. Eventually, the dispersion of coal could be determined from the $\mathrm{SO}_{2} / \mathrm{CO}$ distributions.

According to Einstein Brownian motion theory [41], there is:

$$
D_{n, x}=\frac{\left(\Delta r_{n}\right)^{2}}{2 \Delta t}
$$

where $D_{n, x}$ is the dispersion coefficient of the $n$th particle in the $x$ direction. $\Delta r_{n}$ is the displacement within $\Delta t$ of the single particle. The average dispersion coefficient $D_{x}$ is the mean value of the dispersion coefficients of all particles,

$$
D_{x}=\frac{1}{N} \sum_{n=1}^{N} D_{n, x}=\frac{1}{N} \sum_{n=1}^{N} \frac{\left(\Delta r_{n, x}\right)^{2}}{2 \Delta t}, n=1, \ldots, N
$$

that is,

$$
D_{x}=\frac{1}{2 \Delta t}\left(\frac{1}{N} \sum_{n=1}^{N}\left(\Delta x_{n}\right)^{2}\right)=\frac{1}{2 \Delta t}(\Delta x)^{2}
$$

where $(\Delta x)^{2}$ is defined as the mean square value of displacement of all particles along $x$ direction during $\Delta t$. Since the displacement curve cannot be traced instantly with time, the time needed to carry the particles at the coal feeding ports to the measurement port height was taken as $\Delta t$, and the particle dispersion rates were calculated by combination with $\mathrm{SO}_{2} / \mathrm{CO}$ distributions. In a FB reactor, the particle dispersion rate is closely related to the velocity of fluidization air and bubble behavior, while the rates of bubble breakage and throwing particles are obviously greater than the entrainment rate. Therefore, the area of intense combustion was regarded as the position that the coal was bound to reach. It is extremely difficult to track the accurate time of particle dispersion in the field test. Štefanica et al. [42] has proposed a method to estimate the radial gas dispersion coefficient in a bubbling fluidized bed cold model, but difficult to directly apply in the circulating bed under thermal state. In this paper, $\Delta t$ could be estimated based on the entrainment effect of the fluidization air, as illustrated in Equation (4),

$$
\Delta t=\frac{\Delta H}{u_{p}}=\frac{\Delta H}{u_{g}-u_{t}}
$$

where $\Delta H$ is the distance from the air distributor to the measurement height, $u_{p}$ is the particle velocity, equal to the difference between fluidization air velocity $u_{g}$ and the terminal velocity of particles $u_{t}$.This method to calculate $\Delta t$ was proposed based to two reasons: (1) the particles sampled from the upper measuremenrt port were less than $4 \mathrm{~mm}$, accounting for over $80 \%$ of the feeding coal, and the fine particles could be directly transported vertically to the upper part; (2) this boiler adopted in-furnace desulfurization, the ultra-fine limestone could also be directly entrained upward after entering the furnace. For the solution of particle velocity $u_{p}$, the calculation method of the Reynold number of terminal settlement $R e_{t}$ was introduced in this paper and the influence of particle interaction on settlement velocity was also considered, as shown in Equations (5) and (6) [36].

$$
\begin{gathered}
u_{t}=\frac{v}{d_{p}} R e_{t} \\
\operatorname{Re}_{t}=\frac{\operatorname{Ar}\left(1-\varepsilon_{p}\right)^{4.75}}{18+0.61\left[\operatorname{Ar}\left(1-\varepsilon_{p}\right)^{4.75}\right]^{0.5}}
\end{gathered}
$$

where $d_{p}$ is the particle diameter, $v$ is the kinematic viscosity, $\varepsilon_{p}$ is solid volume fraction and $A r$ is the Archimedes number [25], which indicates the influence of mechanical properties of particles on the mixing rate of particles. 


\subsection{Prediction of Lateral Dispersion Coefficient Based on Local Heat Balance}

The first step is to determine the mass distribution of circulating ash in each cell of the dispersion route. The bed temperature should be evenly distributed if the fuel is not considered. When the feeding coal enters the furnace, the temperature distribution starts to change due to gas absorption, coal combustion and heat exchange between bed and circulating ash, as shown in Figure $4 \mathrm{a}$. When the temperature distribution and flue gas composition are kept constant, it is considered a steady-state condition, and the mass of circulating ash of each cell along the dispersion process reaches a dynamic balance. The heat balance of each cell is as follows,

$$
Q_{b u r n, i}\left(T_{i}\right)=Q_{g, i}\left(T_{i}\right)+Q_{C-B, i}\left(T_{i}\right)
$$

where $Q_{b u r n, i}\left(T_{i}\right)$ is the heat release of fuel particles in cell $i$ at $T$ temperature, $Q_{g, i}$ is the heat absorption of fluidization air and $Q_{C-B, i}$ represents the heat transfer between bed materials and circulating ash. To solve the unknowns in Equation (7), there are,

$$
\begin{gathered}
Q_{\text {burn }, i}=G_{\text {coal }, i} h_{\text {coal }} \\
Q_{g, i}\left(T_{i}\right)=V_{g, i}\left[\rho_{g, i}\left(T_{i}\right) h_{g}\left(T_{i}\right)-\rho_{g, i}\left(T_{0}\right) h_{g}\left(T_{0}\right)\right] \\
Q_{C-B, i}\left(T_{i}\right)=G_{c, i}\left[h_{s}\left(T_{c}\right)-h_{\mathcal{s}}\left(T_{i}\right)\right]
\end{gathered}
$$

where $G_{c, i}$ is the mass flow rate of circulating ash in cell $i$ and can be obtained according to authors' previous study [25], $G_{c o a l, i}$ is the coal feeding rate, $h_{\text {coal }}$ is the low calorific value of the feeding fuel. $V_{g, i}$ is the volume flow rate of primary air. After the preliminary cold test and optimization [40], the PA uniformity has been significantly improved. $\rho_{g, i}$ is the gas density at T temperature. $h_{g}(T)$ and $h_{s}(T)$ respectively correspond to the enthalpy values of the gas and ash at $\mathrm{T}$ temperature.

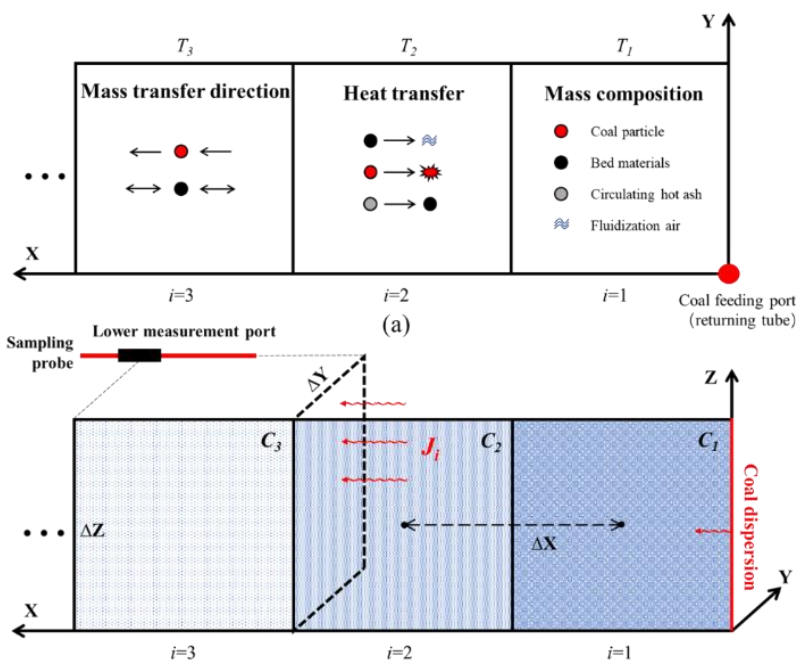

(b)

Figure 4. A schematic diagram of the lateral fuel dispersion process based on the local heat balance method ((a) materials involved in the combustion and heat transfer during solid dispersion; (b) dispersion flux of fuel particles passing through cells).

After obtaining the mass distribution of circulating ash, the lateral dispersion coefficient can be solved because fuel and circulating ash in each cell must came from the lateral dispersion of the only return tube. According to Fick's first law, the dispersion flux J passing through a unit cell perpendicular 
to the dispersion direction in a unit time is proportional to the corresponding concentration gradient. The dispersion coefficient can be described as,

$$
J=\frac{d m_{\text {coal }}}{A d t}=-D_{s r}\left(\frac{\partial C}{\partial x}\right)
$$

where $J$ is the particle dispersion flux passing through a cross-section with area $A, m$ is the mass of fuel particles in cell $i, C$ is the concentration of fuel particles. Due to the fuel particles in the adjacent area must come from the only coal feeding port, the time item can be included in coal feeding rate $G_{c o a l, i}$,

$$
\frac{d m_{\text {coal }}}{A d t}=\frac{G_{c o a l, i}}{\Delta y \Delta z}
$$

where $\Delta y$ and $\Delta z$ are the width and height of the flow section. Also, based on Equations (7)-(10) and Figure $4 b$, the concentration gradient in Equation (11) can be rewritten as,

$$
\frac{\partial C}{\partial x}=\frac{m_{c o a l, i+1}-m_{\text {coal }, i}}{\Delta x^{2} \Delta y \Delta z}
$$

This method has three advantages: (1) The coal feeding rate $G_{c o a l, i}$ (including time item) directly determines the particle dispersion flux $J$. Thus, the time term is included in $G_{c o a l, i}$. This eliminates the calculation of $\Delta t$ that is hard to be determined in the field test; (2) the space length in the $\mathrm{Y} / \mathrm{Z}$ direction can be reduced, so the location of the temperature measurement port has little effect on the measured values. As a result, the lateral dispersion coefficient in different zones can be determined based not only on the adjacent cells but also on the initial feeding position, and the coefficients corresponding to various dispersion distances can also be characterized. (3) the actual coal distribution is different from the initial one during boiler operation; thus, the results obtained through local heat balance are more scientific and realistic.

\section{Results and Discussions}

\subsection{Effect of Fuel Dispersion Process on Flue Gas Composition at the Bottom Zone of the CFB Boiler}

The distributions of flue gas composition $\left(\mathrm{O}_{2}, \mathrm{CO}, \mathrm{SO}_{2}\right.$ and $\left.\mathrm{NO}_{\mathrm{x}}\right)$ along the horizontal direction of the upper measurement port under various cases are shown in Figure 5. Since the center line of the selected coal feeding port was exactly located at the $1500 \mathrm{~mm}$ depth, the lateral dispersion process of fuel particles along both sides should be similar, and the measured results showed obvious symmetrical. At $60 \%$ BMCR load (Case 1 and Case 2), the average $\mathrm{O}_{2}$ concentration exceeded 3.5\%. This distribution first decreased and then increased along the sampling direction, with the lowest value existed at $1500 \mathrm{~mm}$ depth. At $75 \%$ and $100 \%$ BMCR loads, the distributions of $\mathrm{O}_{2}$ concentration were more uniform but the average values were decreased to $3.3 \%$ and $2.6 \%$, respectively. This indicated that the dense phase zone of a large-scale CFB boiler presented a completely opposite combustion atmosphere at different loads, i.e., it showed an oxidizing condition at low load and the distribution of $\mathrm{O}_{2}$ concentration was determined by that of fuel particles. At high load, the furnace showed a reducing condition and the volume flow rate of supplied air could not meet the fully burning of fuel particles. Thus, the $\mathrm{O}_{2}$ concentration showed a more uniform trend. This can also be confirmed by Figure $5 \mathrm{c}$ that no $\mathrm{SO}_{2}$ was detected at low load. With the increase of boiler load, the $\mathrm{SO}_{2}$ concentration gradually increased. 
(a)

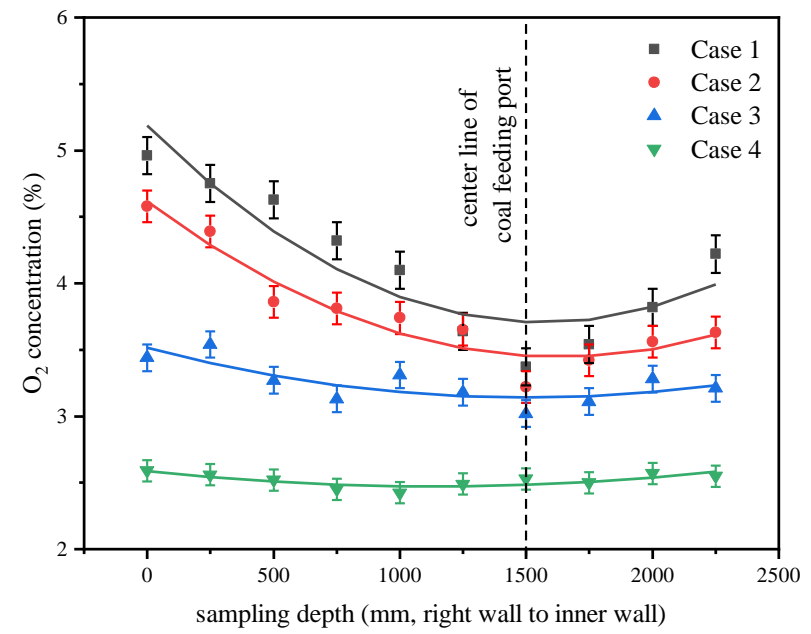

(b)

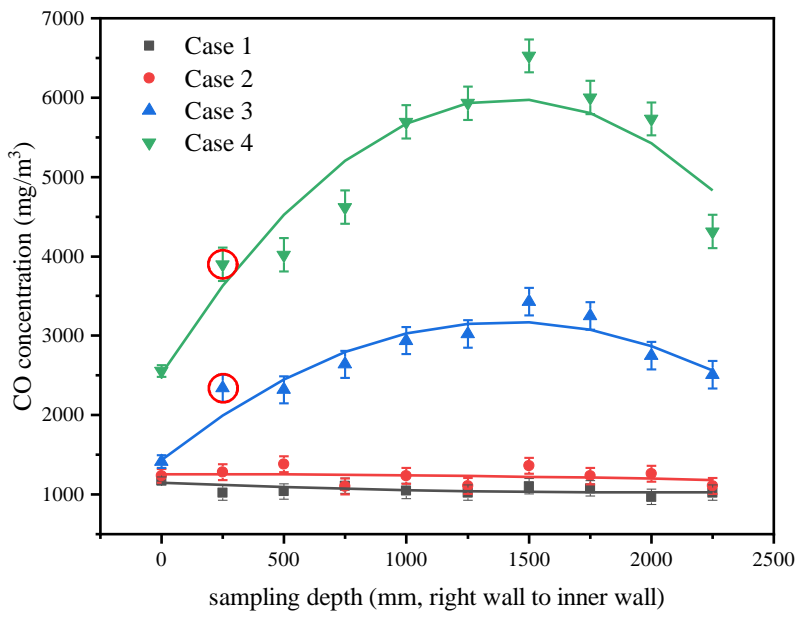

(c)

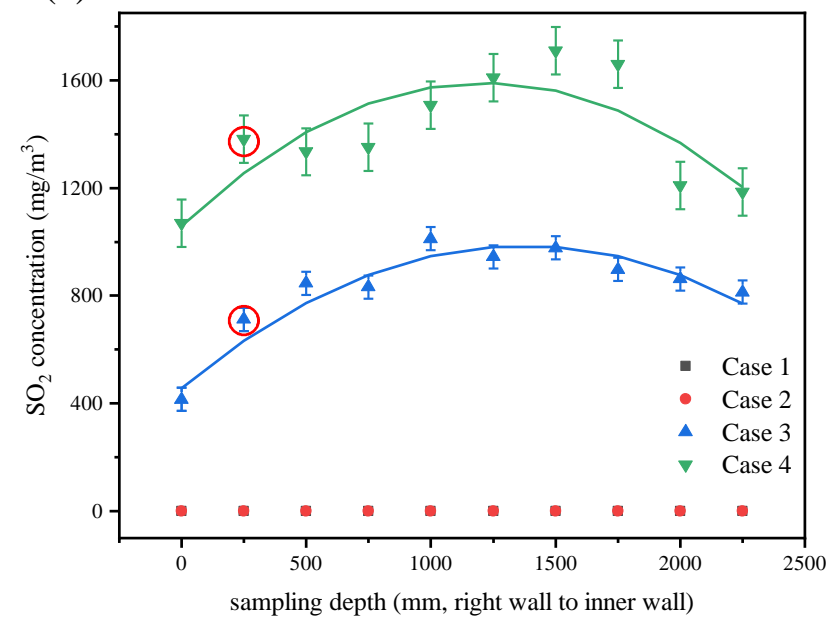

Figure 5. Cont. 
(d)

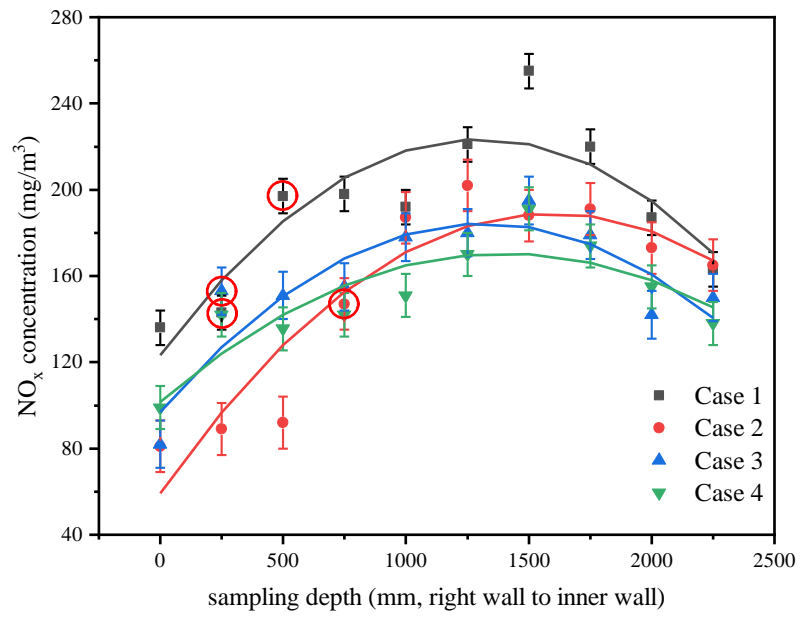

Figure 5. Distributions of flue gas composition along the horizontal direction of the upper measurement port under various working conditions $\left((\mathbf{a}) \mathrm{O}_{2} ;\right.$ (b) $\mathrm{CO} ;(\mathbf{c}) \mathrm{SO}_{2} ;$ (d) $\mathrm{NO}_{x}$; red circled points represent the position that fuel particles are bound to reach).

It can also be concluded from Figure 5 that there were reasonable corresponding relationships between each flue gas composition. The concentration distributions of $\mathrm{SO}_{2}$ and $\mathrm{CO}$ were consistent, but opposite to that of $\mathrm{NO}_{\mathrm{x}}$. At low load, the $\mathrm{CO}$ concentration was at a low level and evenly distributed due to relatively sufficient oxygen, but the $\mathrm{NO}_{x}$ concentration was higher and the gradient was larger. In the zone near the right wall, the $\mathrm{NO}_{\mathrm{x}}$ concentrations at high loads were higher than those in Case 2 . It is considered that more fuel was dispersed into adjacent zones at high load, and the combustion of volatiles promoted the formation of more $\mathrm{NO}_{x}$.

\subsection{Calculation Results of Lateral Fuel Dispersion Coefficient}

\subsubsection{Dispersion Model Method}

In this method, the key goal is to determine the particle dispersion positions There was only one coal feeding port and was not affected by the secondary air jet. Also, the PA was evenly distributed. Therefore, the changes of gas composition directly reflected the mass of fuel in each local part. When the concentration gradient of one key composition increased significantly, it showed to be the boundary of fuel particle dispersion. Thus, the lateral fuel dispersion can be predicted reasonably by combining with the measured flue gas composition [43], i.e., the position of coal dispersion was determined based on the distributions of $\mathrm{CO} / \mathrm{SO}_{2}$ concentration at high load, and based on $\mathrm{NO}_{\mathrm{x}}$ concentration at low load. These positions have been marked with red circles in Figure 5. At 60\% BMCR load, the dispersion distance of fuel particles in Case 1 was longer than that in Case 2. Although higher PA velocity promoted the mixing of fuel and bed materials, the static bed height in Case 2 was higher, and the height of dense phase zone in fluidization condition can be calculated by Equation (14) [44],

$$
H_{\text {den }}=R_{\text {den }} H_{0}
$$

where $H_{0}$ is the static bed height, and the expansion ratio $R_{d e n}$ can be described as Equation (15) [45],

$$
R_{\text {den }}=\left\{\begin{array}{cl}
6.01\left(d_{p} \rho_{p}\right)^{0.3}\left(u_{g} / u_{t}\right), & u_{g} / u_{t}>0.267\left(d_{p} \rho_{p}\right)^{-0.6} \\
3.1\left(u_{g} / u_{t}\right)^{0.5}, & \left.u_{g} / u_{t}<0.267\left(d_{p}\right] \rho_{p}\right)^{-0.6}
\end{array}\right.
$$

where $\rho_{p}$ is the density of particles. Accordingly, the height of the coal feeding port $(H=1200 \mathrm{~mm})$ was completely immersed in Case 2, while consistent with the $H_{\text {den }}$ in Case 1 . Therefore, compared with 
increasing the fluidization velocity, the throwing and collision of the particles caused by bubble breakage were more conducive to the mixing of fuel particles in the horizontal direction when the particle injection position was close to $H_{d e n}$. With the increase of boiler loads (Case 1, 3 and 4), the dispersion positions of fuel particles extended from $X=500 \mathrm{~mm}$ to $250 \mathrm{~mm}$. In addition to the increasing fluidization velocity, the flow rate of circulating ash at high load was larger, which could strengthen the ash spreading to improve the ability of lateral fuel dispersion. According to the above analyses, especially the determined locations of fuel particles, the lateral dispersion coefficient can be calculated based on the dispersion model.

\subsubsection{Local Heat Balance Method}

The distributions of mixed bed temperature along the horizontal direction of the lower measurement port at various cases are shown in Figure 6. The circulating ash temperature were also marked as auxiliary lines in the figure to reflect the temperature differences. Except $X=1000 \mathrm{~mm}$ in Case 1, the temperature from the coal feeding port $(X=1500 \mathrm{~mm})$ to the right wall decreased with a maximum temperature deviation up to $30^{\circ} \mathrm{C}$. With the increase of boiler loads, the temperature of circulating ash increased from $840^{\circ} \mathrm{C}$ to $900^{\circ} \mathrm{C}$ and gradually exceeded the corresponding mixed bed temperature under stable conditions. In Case 2, the heat transfer between particles dominated within $X=0-500 \mathrm{~mm}$ as the circulating ash temperature was higher than the mixed bed temperature. While at $X=500-1500 \mathrm{~mm}$, the circulating ash absorbed heat from the bed, and the distribution of bed temperature mainly came from the heat release of fuel particles in different zones. Thus, it can be concluded that the stable distribution of bed temperature at low load is affected by fuel dispersion characteristics and combustion, while greatly affected by circulating ash temperature at high load. Thus, the dispersion coefficients of fuel particles in different cells can be calculated based on the local heat balance in dense phase zone.

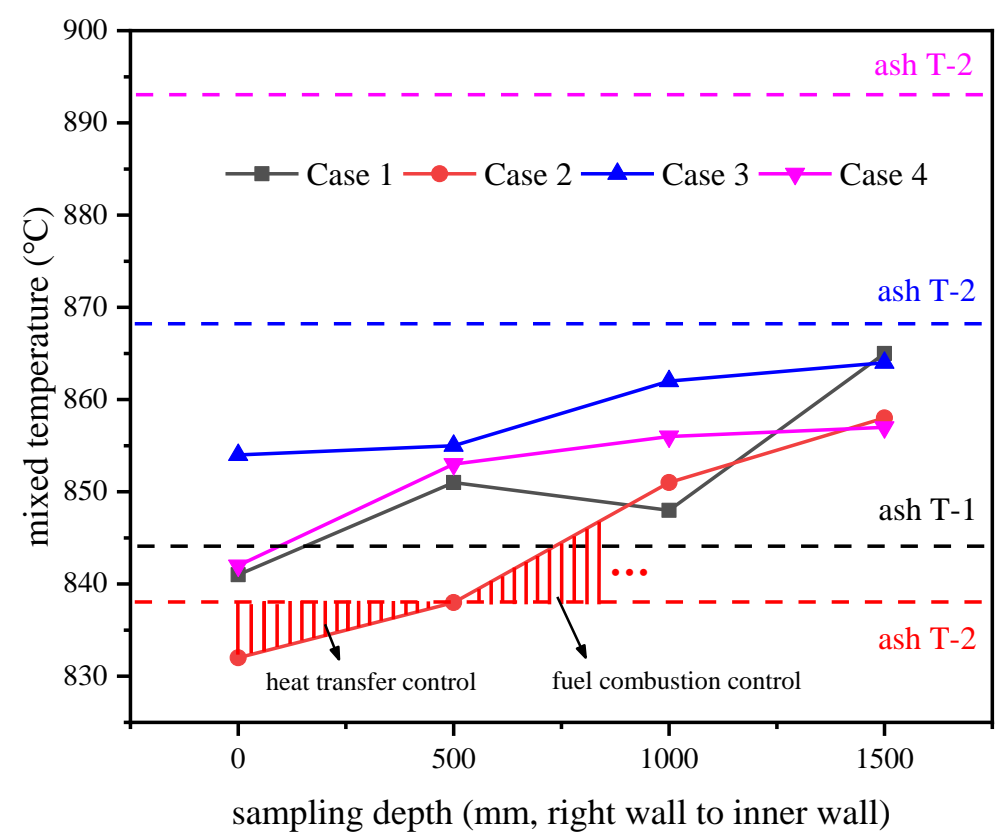

Figure 6. Distributions of mixed bed temperature along the horizontal direction of the lower measurement port at various cases.

\subsubsection{Results and Comparison of the Two Methods}

The lateral fuel dispersion coefficients $D_{s r}$ calculated through the two methods are shown in Figure 7. With changes in load and operation parameters, the $D_{s r}$ ranged from 0.10 to $0.35 \mathrm{~m}^{2} / \mathrm{s}$, which were significantly higher than the results of most literature [26,27,30-33], but in the same order 
of magnitude as the predicted values from Liu [24] and Schlichthaerle [29]. Under various working conditions, the $D_{s r}$ obtained from the dispersion model were 9-18\% lower than the average $D_{s r}$ from the local heat balance method. This was mainly attributed to the selection of $\Delta t$, which had a certain influence on the calculation of $D_{s r}[25,31]$.

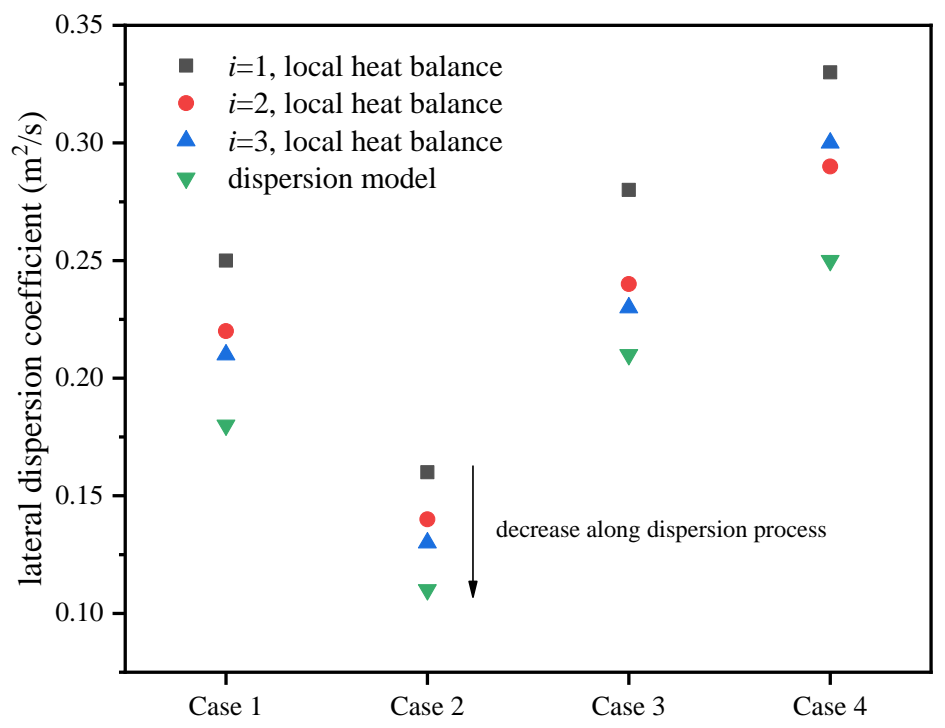

Figure 7. Comparison of lateral fuel dispersion coefficients based on the dispersion model and the local heat balance method.

With the increase of boiler loads, the $D_{s r}$ calculated by the local heat balance increased gradually, which were consistent with the criterion from flue gas composition. Under the same case, the $D_{s r}$ along lateral direction $(i=1,2,3)$ showed a gradual decreasing trend. There are three reasons for this. First, the initial momentum of fuel particles from the coal feeding port still existed and gradually lost during the dispersion process. Secondly, due to a certain proportion of fuel combustion in the dispersion process, the actual fuel concentrations far away from the coal feeding port were less than the theoretical values. In Case 4, the $D_{s r}$ of cell 3 were higher than those of cell 2, which might be due to the influence of the fuel dispersed from the adjacent coal feeding port. Judged from the results, the average deviation caused by this factor did not exceed $15 \%$. In addition, the $D_{s r}$ of Case 2 was about $34.7 \%$ lower than that of Case 1 at $60 \%$ BMCR load. Although the velocity of fluidization air in Case 2 was higher, the coal feeding port was immersed in the expanded bed, which greatly restricted the dispersion ability of fuel particles.

\subsubsection{Application and Validation}

The 600 MW CFB boiler adopted the scraper conveyor to feed the coal with circulating ash, while many others adopted the screw feeder with pressurized air to spread the fuel [46]. Hence, the universality of this calculation method was applied and verified in a $300 \mathrm{MW}$ CFB boiler. Under some extreme working condition, the \#1 and \#2 coal feeding port (1100 $\mathrm{mm}$ above the air distributor) were in a coal cut-off state, as shown in Figure 8, and the temperature of bed and circulating ash are exhibited in Table 4. It can be concluded that the coal in these zones were completely from the lateral dispersion of coal particles at the \#3 coal feeding port. 


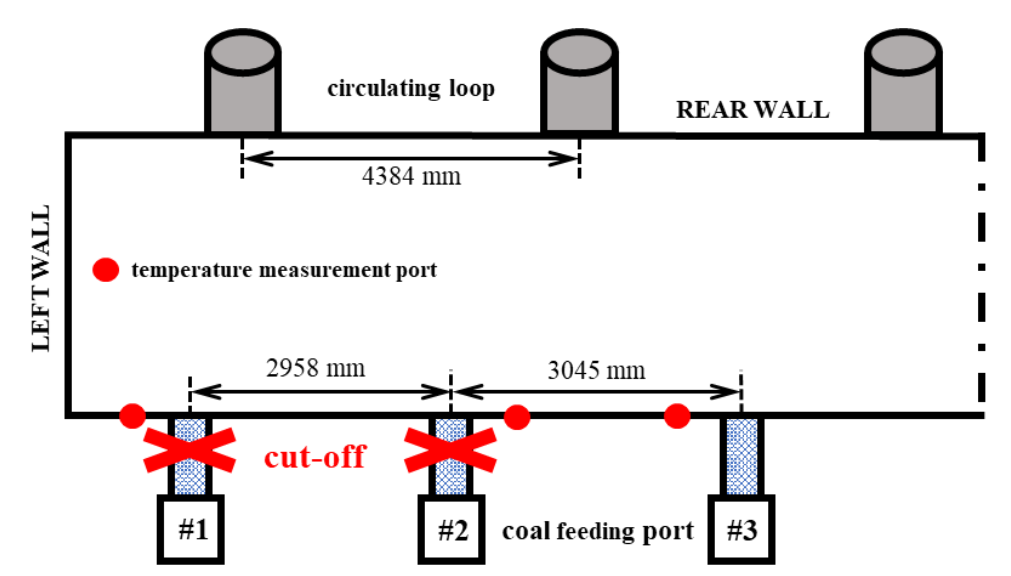

Figure 8. A schematic diagram of the $300 \mathrm{MW}$ CFB boiler under the condition of local coal cut-off.

Table 4. Temperature distributions and calculated lateral fuel dispersion coefficients under the coal cut-off condition.

\begin{tabular}{cccc}
\hline Item & \#1 & \#2 & \#3 \\
\hline Bed temperature $\left({ }^{\circ} \mathrm{C}\right)$ & 797 & 875 & 903 \\
Temperature of circulating ash $\left({ }^{\circ} \mathrm{C}\right)$ & 735 & 831 & 912 \\
$D_{s r}\left(\mathrm{~m}^{2} / \mathrm{s}\right)$ & 0.12 & 0.16 & $/$ \\
\hline
\end{tabular}

Based on the local heat balance method, the $D_{s r}$ of fuel particles dispersed from \#3 port to the zones near the \#2 and \#1 ports were 0.16 and $0.12 \mathrm{~m}^{2} / \mathrm{s}$ respectively. The calculated values also showed a decreasing trend along the lateral direction, which were similar to the results of the $600 \mathrm{MW}$ CFB boiler. The values of the two coal feeding modes were in the order of $0.1 \mathrm{~m}^{2} / \mathrm{s}$, but the latter was obviously lower. Compared with the coal feeding port, the cross-sectional area and solid flow rate of the returning tube were much larger. These factors provided a good prerequisite for the radial spreading and lateral dispersion of fuel particles.

\section{Conclusions}

To investigate the lateral dispersion characteristics of fuel particles in large-scale CFB boilers, field tests were conducted on the first $600 \mathrm{MW}$ supercritical CFB boiler. The distributions of flue gas composition and temperature near the coal feeding port under four working conditions were obtained, and the influence of operating parameters on the dispersion process were analyzed. In addition to the traditional dispersion model, a simple method for calculating the lateral fuel dispersion coefficient by using the local heat balance was also proposed, and the results of the two methods were compared. Under the extreme working condition of fuel cut-off, the local heat balance method was applied and validated in a 300 MW CFB boiler with a different coal feeding mode. The conclusions related to fuel dispersion are as follows:

(1) The lateral fuel dispersion coefficients through the local heat balance method ranged from $0.10-0.35 \mathrm{~m}^{2} / \mathrm{s}$ and increased with boiler load increasing. The values were $9-18 \%$ higher than those of the dispersion model. When the coal feeding port was below the expanded bed, the fuel dispersion would be greatly limited. Compared with that in the splash zone, the calculated lateral dispersion coefficient decreased by about $34.7 \%$.

(2) Based on the local heat balance method, the lateral fuel dispersion coefficient of various CFB boilers could be calculated. The predicted values under the coal feeding mode of a screw feeder with pressurized air ranged from $0.12-0.16 \mathrm{~m}^{2} / \mathrm{s}$, which were lower than those adopted the scraper conveyor to feed the coal with circulating ash, but still in the same order of magnitude. 
Author Contributions: Conceptualization, X.L. (Xiaofeng Lu) and J.Y.; investigation, J.Y., X.F. and X.L. (Xiaofeng Lu); methodology, X.L. (Xiaofeng Lu) and J.Y.; writing—original draft preparation, J.Y.; writing-review and editing, X.L. (Xiaofeng Lu), X.Z. and R.X.; validation, S.L. and X.L. (Xiujian Lei). All authors have read and agreed to the published version of the manuscript.

Funding: This work was supported by the National Key Research \& Development Program of China (No. 2016YFB0600201) and the Scientific Research Start-up Foundation funding of High-level Introduction Talents of Nanjing Institute of Technology (Grants No. YKJ201962).

Acknowledgments: Authors are thankful to Xiong Xie, Changxu Liu from Baima Power Plant, and Zhenguo Yang, Liyuan Fan, Huixin Yang from Wu'an Power Plant for valuable support during the field tests over the past year.

Conflicts of Interest: The authors declare no conflict of interest.

\section{Nomenclature}

\begin{tabular}{|c|c|}
\hline$A$ & Area of flow section, $\mathrm{m}^{2}$ \\
\hline$A_{a d}$ & Ash content in fuel (wt $\%$, air dry basis) \\
\hline$A r$ & Archimedes number \\
\hline$B M C R$ & Boiler maximum continuous rating \\
\hline C & Concentration of fuel particles, $\mathrm{kg} / \mathrm{m}^{3}$ \\
\hline$D_{n, x}$ & Dispersion coefficient of a single particle along $\mathrm{x}$ direction, $\mathrm{m}^{2} / \mathrm{s}$ \\
\hline$D_{s r}$ & Lateral dispersion coefficient of fuel particles, $\mathrm{m}^{2} / \mathrm{s}$ \\
\hline$d_{p}$ & Diameter of the particles, $\mathrm{m}$ \\
\hline$E H E_{S}$ & External heat exchanger \\
\hline$F c_{a d}$ & Fixed carbon content in fuel (wt $\%$, air dry basis) \\
\hline G & Mass flow rate of coal $/ \mathrm{ash}, \mathrm{kg} / \mathrm{s}$ \\
\hline$H_{0}$ & Static bed height, $\mathrm{m}$ \\
\hline$H_{\text {den }}$ & Height of dense phase zone at fluidization state, $\mathrm{m}$ \\
\hline$h$ & Specific enthalpy, kJ/kg \\
\hline ILSA & Inner lower secondary air \\
\hline IUSA & Inner upper secondary air \\
\hline$J$ & Fuel dispersion flux, $\mathrm{kg} /\left(\mathrm{m}^{2} \cdot \mathrm{s}\right)$ \\
\hline$M_{a d}$ & Moisture content in fuel (wt $\%$, air dry basis) \\
\hline$m$ & mass of fuel particles in a certain area, $\mathrm{kg}$ \\
\hline$N$ & Particle numbers \\
\hline OUSA & Outer upper secondary air \\
\hline$P A$ & Primary air \\
\hline$Q$ & Heat absorption, $\mathrm{kW}$ \\
\hline$R$ & Diameter of fuel particles, $\mathrm{mm}$ \\
\hline$R e_{t}$ & the Reynold number of terminal settlement \\
\hline$R_{\text {den }}$ & Expansion ratio \\
\hline$S A$ & Secondary air \\
\hline$T$ & Temperature, ${ }^{\circ} \mathrm{C}$ \\
\hline$u_{g}$ & Fluidization velocity, $\mathrm{m} / \mathrm{s}$ \\
\hline$u_{p}$ & Particle velocity, m/s \\
\hline$u_{t}$ & Terminal velocity of particles, $\mathrm{m} / \mathrm{s}$ \\
\hline$V$ & Volume flow rate of $\mathrm{PA}, \mathrm{Nm}^{3} / \mathrm{s}$ \\
\hline$V_{a d}$ & Volatiles content in fuel (wt\%, air dry basis) \\
\hline \multicolumn{2}{|c|}{ Greek symbols } \\
\hline$\Delta x$ & Particles displacement along the $x$ direction, $\mathrm{m}$ \\
\hline$\Delta y$ & Width of the flow section, $\mathrm{m}$ \\
\hline$\Delta z$ & Height of the flow section, $\mathrm{m}$ \\
\hline$\Delta t$ & $\begin{array}{l}\text { Time required to carry particles from coal feeding port to the } \\
\text { measurement height, s }\end{array}$ \\
\hline
\end{tabular}




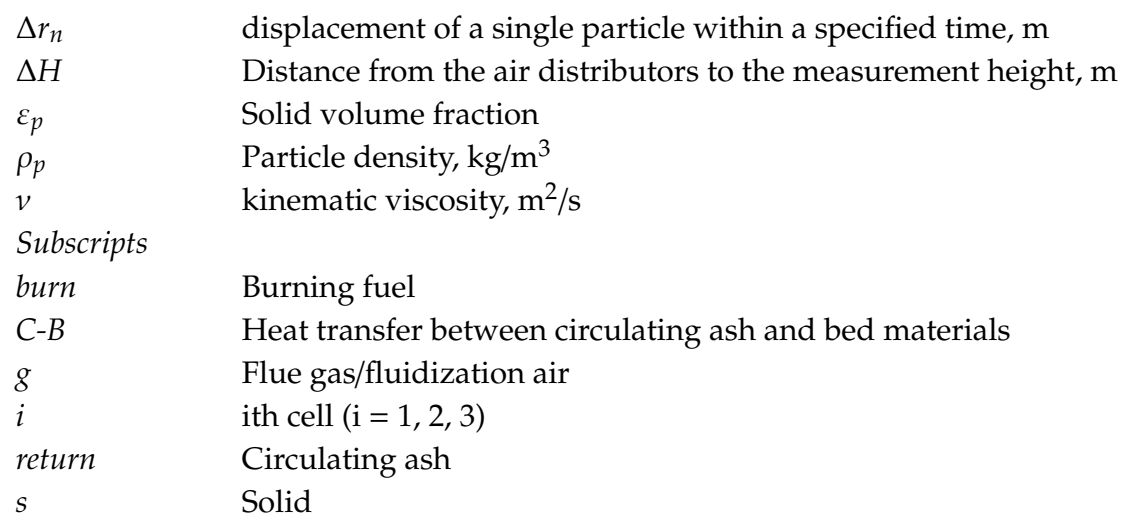

\section{References}

1. Yue, G.X.; Cai, R.X.; Lyu, J.F.; Zhang, H. From a CFB reactor to a CFB boiler-The review of R\&D progress of CFB coal combustion technology in China. Powder Technol. 2017, 316, 18-28.

2. Liu, X.M.; Yang, H.R.; Lyu, J.F. Optimization of Fluidization State of a Circulating Fluidized Bed Boiler for Economical Operation. Energies 2020, 13, 376. [CrossRef]

3. Cheng, L.M.; Qiang, J.J.; Wei, Y.J.; Wang, Q.H.; Fang, M.X.; Luo, Z.Y.; Ni, M.J.; Cen, K.F. A note on large-size supercritical CFB technology development. Powder Technol. 2020, 363, 398-407. [CrossRef]

4. Li, D.F.; Ke, X.W.; Yang, H.R.; Ahn, S.G.; Lyu, J.F.; Jeon, C.H.; Zhang, M. The ash formation and attrition characteristics of an Indonesia lignite coal ash for a 550 MWe ultra supercritical CFB boiler. Chem. Eng. Res. Des. 2019, 147, 579-586. [CrossRef]

5. Basu, P. Combustion of coal in circulating fluidized-bed boilers: A review. Chem. Eng. Sci. 1999, 54, 5547-5557. [CrossRef]

6. Nowak, W.; Mirek, P. Circulating Fluidized Bed Combustion (CFBC), Chapter 16 in. Fluidized Bed Technologies for Near-Zero Emission Combustion and Gasification; Scala, F., Ed.; Woodhead Publishing: London, UK, 2013; Volume 541, pp. 701-764.

7. Oka, S.N. Fluidized Bed Combustion; CRC Press: Boca Raton, FL, USA, 2003.

8. Leckner, B.; Szentannai, P.; Winter, F. Scale-up of fluidized-bed combustion-A review. Fuel 2011, 90, 2951-2965. [CrossRef]

9. Blaszczuk, A.; Nowak, W. Heat transfer behavior inside a furnace chamber of large-scale supercritical CFB reactor. Int. J. Heat Mass Tran. 2015, 87, 464-480. [CrossRef]

10. Zheng, W.J.; Zhang, M.; Zhang, Y.; Lyu, J.F.; Yang, H.R. The effect of the secondary air injection on the gas-solid flow characteristics in the circulating fluidized bed. Chem. Eng. Res. Des. 2019, 141, 220-228. [CrossRef]

11. Kunii, D.; Levenspiel, O. Fluidization Engineering, 2nd ed.; Butterworth-Heinemann Press: Boston, MA, USA, 1991.

12. Svensson, A.; Johnsson, F.; Leckner, B. Bottom bed regimes in a circulating fluidized bed boiler. Int. J. Multiphas. Flow. 1996, 22, 1187-1204. [CrossRef]

13. Peng, Z.B.; Alghamdi, Y.; Moghtaderi, B.; Doroodchi, E. CFD-DEM investigation of transition from segregation to mixing of binary solids in gas fluidised beds. Adv. Powder Technol. 2016, 27, 2342-2353. [CrossRef]

14. Peng, Z.B.; Doroodchi, E.; Alghamdi, Y.; Moghtaderi, B. Mixing and segregation of solid mixtures in bubbling fluidized beds under conditions pertinent to the fuel reactor of a chemical looping system. Powder Technol. 2013, 235, 823-837. [CrossRef]

15. Lin, J.J.; Luo, K.; Wang, S.; Sun, L.Y.; Fan, J.R. Particle-Scale Simulation of Solid Mixing Characteristics of Binary Particles in a Bubbling Fluidized Bed. Energies 2020, 13, 4442. [CrossRef]

16. Peng, Z.B.; Moghtaderi, B.; Doroodchi, E. A simple model for predicting solid concentration distribution in binary-solid liquid fluidized beds. AICHE J. 2017, 63, 469-484. [CrossRef]

17. Doraiswamy, L.K.; Kulkarni, B.D. Transport Processes in Fluidized Bed Reactors, Advances in Transport Processes; Wiley Eastern Limited: New Delhi, India, 1987; Volume VII, p. 242.

18. Hartge, E.U.; Evard, M. Gas distribution via nozzles-Design and operational experience. In Proceedings of the VGB Workshop, Operating Experience with Fluidised Bed Firing Systems, Berlin, Germany, 22-24 September 2004. 
19. Johnsson, F.; Larsson, G.; Leckner, B. Pressure and flow fluctuations in a fluidized bed interaction with the air-feed system. Chem. Eng. Sci. 2002, 57, 1379-1392. [CrossRef]

20. Chyang, C.S.; Han, Y.L.; Chien, C.H. Gas dispersion in a rectangular bubbling fluidized bed. J. Taiwan Inst. Chem. Eng. 2010, 41, 195-202. [CrossRef]

21. Mirek, P. Designing of primary air nozzles for large-scale CFB boilers in a combined numerical-experimental approach. Chem. Eng. Process. 2011, 50, 694-701. [CrossRef]

22. Pallarès, D.; Johnsson, F. Time-resolved modeling of gas mixing in fluidized bed units. Fuel Process. Technol. 2015, 134, 73-84. [CrossRef]

23. Sánchez-Prieto, J.; Hernández-Jiménez, F.; Garcia-Gutierrez, L.M.; Soria-Verdugo, A. Experimental study on the characteristic mixing time of solids and its link with the lateral dispersion coefficient in bubbling fluidized beds. Chem. Eng. J. 2017, 307, 113-121. [CrossRef]

24. Liu, D.Y.; Chen, X.P. Lateral solids dispersion coefficient in large-scale fluidized beds. Combust. Flame 2010, 157, 2116-2124. [CrossRef]

25. Liu, D.Y. Experimental and Numerical Researches on the Particle Mixing in Fluidized Beds. Ph.D. Thesis, Southeast University, Nanjing, China, 2011.

26. Liu, D.Y.; Chen, X.P.; Tang, Z.; Zhao, C.-S. Experimental study on the mixing of particles feeding into the bottom of a CFB. J. Eng. Thermophys. 2009, 30, 529-532.

27. Olsson, J.; Pallares, D.; Johnsson, F. Lateral fuel dispersion in a large-scale bubbling fluidized bed. Chem. Eng. Sci. 2012, 74, 148-159. [CrossRef]

28. Hu, N.; Guo, Z.J.; Yang, H.R.; Lyu, J.F.; Pei, Y.F. Experimental study on lateral dispersion coefficient of solid particles in a CFB boiler. J. Chinese Soc. Power Eng. 2016, 36, 168-171.

29. Schlichthaerle, P.; Werther, J. Solids mixing in the bottom zone of a circulating fluidized bed. Powder Technol. 2001, 120, 21-33. [CrossRef]

30. Yang, H.R.; Lyu, J.F.; Liu, Q.; Yue, G.X. A study of the transverse dispersion of solid particles in the dense-phase zone of a circulating fluidized bed boiler. J. Eng. Therm. Power. 2001, 16, 395-398.

31. Gan, L.; Lu, X.F.; Wang, Q.H.; Hu, Q.; Chen, Y.; Xu, J. Experimental study on lateral mixing of particles in a quasi-slot-rectangular spouted bed. Powder Technol. 2013, 243, 1-8. [CrossRef]

32. Oke, O.; Lettieri, P.; Salatino, P.; Solimene, R.; Mazzei, L. Numerical simulations of lateral solid mixing in gas-fluidized beds. Chem. Eng. Sci. 2014, 120, 117-129. [CrossRef]

33. Oke, O.; Wachem, B.V.; Mazzei, L. Lateral solid mixing in gas-fluidized beds: CFD and DEM studies. Chem. Eng. Res. Des. 2016, 114, 148-161. [CrossRef]

34. Chirone, R.; Miccio, F.; Scala, F. On the relevance of axial and transversal fuel segregation during the FB combustion of a biomass. Energy Fuel 2004, 18, 1108-1117. [CrossRef]

35. Yan, J.; Lu, X.F.; Xue, R.; Lu, J.Y.; Zheng, Y.; Zhang, Y.; Liu, Z. Validation and application of CPFD model in simulating gas-solid flow and combustion of a supercritical CFB boiler with improved inlet boundary conditions. Fuel Process. Technol. 2020, 208, 106512. [CrossRef]

36. Lu, X.F. Equipments and Operation of Large-Scale Circulating Fluidized Bed Boiler; Electric Power Press: Beijing, China, 2006.

37. Song, G.L.; Yang, Z.; Zhou, T.; Lyu, Q.G. Operating technical characteristics on asymmetrical arrangement of six cyclones in a 600MW supercritical CFB boiler. Appl. Therm. Eng. 2018, 143, 236-247. [CrossRef]

38. Lu, J.Y.; Lu, X.F.; He, H.H.; Wang, H.; Gan, L.; Zhao, P.; Tang, X.N. Combustion characteristics of the external circulation loop on Baima's 300 MWe circulating fluidized bed boiler. Energy Fuel 2011, 25, 3456-3464. [CrossRef]

39. Yan, J.; Lu, X.F.; Wang, Q.H.; Kang, Y.H.; Li, J.B.; Xu, Z.; Lei, X.; Zheng, X.; Fan, X.; Liu, Z. Study on the influence of secondary air on the distributions of flue gas composition at the lower part of a $600 \mathrm{MW}$ supercritical CFB boiler. Fuel Process. Technol. 2019, 196, 106035. [CrossRef]

40. Yan, J.; Lu, X.F.; Wang, Q.H.; Kang, Y.H.; Li, J.B.; Zhou, J.; Zhang, Y.; Lv, Z.; Sicong, S. Experimental and numerical study on air flow uniformity in the isobaric windbox of a $600 \mathrm{MW}$ supercritical CFB boiler. Appl. Therm. Eng. 2017, 122, 311-321. [CrossRef]

41. Einstein, A. Investigations on the Theory of the Brownian Movement; Dover Publication: New York, NY, USA, 1956.

42. Štefanica, J.; Hrdlička, J. Experimental Investigation of Radial Gas Dispersion Coefficients in a Fluidized Bed. Acta Polytech. 2012, 52, 97-100.

43. Grace, J.R.; Avidan, A.A.; Knowlton, T.M. Circulating Fluidized Beds; Springer: Heidelberg, Germany, 1997. 
44. Cheng, L.M.; Cen, K.F.; Ni, M.J.; Luo, Z.Y. Thermal calculation of a circulating fluidized bed boiler furnace. J. CSEE 2002, 22, 146-151.

45. Boiler Section, Electricity Department, Tsinghua University. Fluidized Combustion Boiler; Science Press: Beijing, China, 1972.

46. Farid, M.M.; Jeong, H.J.; Kim, K.H.; Lee, J.M.; Kim, D.W.; Hwang, J.H. Numerical investigation of particle transport hydrodynamics and coal combustion in an industrial-scale circulating fluidized bed combustor: Effects of coal feeder positions and coal feeding rates. Fuel 2017, 192, 187-200. [CrossRef]

Publisher's Note: MDPI stays neutral with regard to jurisdictional claims in published maps and institutional affiliations.

(C) 2020 by the authors. Licensee MDPI, Basel, Switzerland. This article is an open access article distributed under the terms and conditions of the Creative Commons Attribution (CC BY) license (http://creativecommons.org/licenses/by/4.0/). 